\title{
The link between particle size and froth stability - implications for reprocessing of flotation tailings
}

\author{
Mackay I.*a, Videla A.R. ${ }^{\text {, }}$, Brito-Parada P.R.*a \\ ${ }^{a}$ Department of Earth Science and Engineering, Imperial College London, SW7 2AZ, United Kingdom \\ ${ }^{b}$ Department of Mining Engineering, Pontificia Universidad Catolica de Chile, 7820436, Chile \\ *Corresponding Authors: isobel.mackay11@imperial.ac.uk and p.brito-parada@imperial.ac.uk
}

\begin{abstract}
Historic tailings dams can often be considered as valuable mineral reserves due to the declining head grades of primary deposits. The reprocessing of such material is of great interest to the minerals processing industry, not only from an economic point of view, but also from an environmental one. However, tailings material is generally comprised of fine particles, which poses a challenge for its reprocessing using froth flotation due to reduced recoveries of these particle sizes. In addition, there is some debate as to the effect that these fine particles have on the froth stability, which in turn is linked to mineral recovery.

In this work, air recovery was used as a measure of froth stability to determine the flotation response of a copper tailings ore to changes in particle size distribution and superficial gas velocity. The system exhibited a maximum in air recovery, which correlates well with the local peak in dynamic froth stability presented in previous work. This maximum in froth stability is also shown to correspond to an improvement in flotation performance, thus highlighting the importance of considering the link between particle size, air rate and froth stability when determining the flotation strategy for tailings reprocessing. The results are discussed in terms of the implications for the reprocessing plant from where the ore samples were obtained and, more generally, for the efficient flotation reprocessing of tailings.
\end{abstract}

Keywords: Froth flotation, Stability, Air Recovery, Copper Tailings Reprocessing, Continuous Flotation

https://doi.org/10.1016/j.jclepro.2019.118436

Copyright (c) 2019. This manuscript version is made available under the CC-BY-NC-ND 4.0 license (http://creativecommons.org/licenses/by-nc-nd/4.0/)

\section{Introduction}

The global demand for metals, such as copper, is increasing, putting a strain on mining companies as head grades of deposits decrease. At the beginning of the $20^{\text {th }}$ century copper tailings dams had an average copper content (or grade) of $0.75 \%$, while today they are as low as $0.14 \%$ (Gordon, 2002). This drop is due to an improvement in processing efficiency (Falagán et al., 2017). Reprocessing historic tailings dams is therefore attractive to the mining industry, as they are relatively high grade in comparison to modern reserves. There are also other benefits, for in- stance, there is no comminution requirement. Added to this, by reprocessing the waste material, mining companies can reduce the significant environmental problems associated with tailings dams (Chen et al., 2014).

One of the most widely used separation techniques across the minerals processing industry is froth flotation, a technique that utilises the differences in surface properties to separate valuable minerals from the waste material (Fuerstenau et al., 2007). Due to the relative versatility of flotation, especially with regards to complex and low grade ores, this technique is commonly used for the reprocessing of tailings ma- 
terial (Wills and Finch, 2015). However, one of the major challenges presented by reprocessing tailings material in this way is that it contains a large portion of fine and ultra-fine particles, which are harder to process using froth flotation (Edraki et al., 2014). It is therefore vital to carry out research into understanding the effects of different operating conditions on the flotation performance of tailings material.

There have been numerous recent studies investigating the potential for reprocessing tailings ores using froth flotation for a variety of different ore types such as copper (Lutandula and Maloba, 2013; Alcalde et al., 2018; Mackay et al., 2018; Yin et al., 2018), gold (Valderrama and Rubio, 2007), zinc (Yang et al., 2015; Babel et al., 2018) and cassiterite (Leistner et al., 2016). These studies have shown that there is good potential for the reprocessing of the various tailings types investigated. However, each of the aforementioned papers presents a different solution to the general problem that is specific to that ore. Due to the case-specific nature of tailings material, it is challenging to develop a generic framework for tailings management (Adiansyah et al., 2015). The present study will investigate the ability to improve the flotation recovery of valuable minerals from tailings materials by altering the feed particle size distribution.

\subsection{Fine Particle Flotation}

Due to the fact that the majority of particles in tailings dams are fine (less than $50 \mu \mathrm{m}$ ), it is important to understand the challenges of successfully floating such material and what effects the presence of the fine particles has on froth stability and therefore flotation performance. The first major problem when recovering fine or ultrafine particles through froth flotation is that, due to their higher specific surface area, they consume larger quantities of reagents (Feng and Aldrich, 1999). The second problem is that there is a much lower probability of the particle attaching to the bubble (Miettinen et al., 2010). The third problem is that, the small size of the particles results in lower settling velocities and particles are therefore more easily entrained (Neethling and Cilliers, 2009). For more detail into the problems associated with fine particle flotation the reader is directed to Miettinen et al. (2010), which presents an in depth review paper on the matter.

Whilst it is well known that fine particle recovery in froth flotation is poor (Fuerstenau et al., 2007), there have also been several studies investigating the effects that the amount of fine particles in the feed has on the recovery of different particle sizes in the system. These studies have shown that the presence of fine particles, to some extent, can improve the flotation recoveries of other particles in the system. Vieira and Peres (2007) conducted laboratory experiments in a Denver flotation cell to investigate this, varying the proportion of fine $(38-74 \mu \mathrm{m})$ quartz particles in the feed from none to $15.6 \%$, and measuring the recoveries of the fine, medium and coarse quartz particles were measured. The results showed that the feed with and intermediate proportion of fine quartz particles $(11.6 \%)$ improved the recovery of all three size fractions. The authors proposed that this effect was due to the presence of fine particles stabilising the froth, however the froth stability was not quantified in this work. Conversely, flotation experiments conducted by Rahman et al. (2012) showed that when changing the feed size of silica particles in a laboratory scale flotation column, it was the finest feed (with a $d_{80}$ of $80 \mu \mathrm{m}$ ) that resulted in increased recoveries of the coarser particle sizes $(>90 \mu \mathrm{m})$. The work by Rahman et al. (2012) also showed that an intermediate feed size (with a $d_{80}$ of $150 \mu \mathrm{m}$ ) resulted in improved recoveries of the finest three particle sizes (10 $\mu \mathrm{m}, 36 \mu \mathrm{m}$ and $64 \mu \mathrm{m})$.

Both Vieira and Peres (2007) and Rahman et al. (2012) used single species systems in their flotation experiments. On the other hand, Leistner et al. (2017) investigated the effects of varying the particle size of both valuable and gangue minerals on the recovery using a laboratory scale flotation cell. Their study used fine $(10-50 \mu \mathrm{m})$ and ultrafine $(<10 \mu \mathrm{m})$ magnetite as the valuable material, in the presence of fine and ultrafine quartz as the gangue material. The results showed that the presence of fine quartz particles increased the recovery of both sizes of magnetite, whilst the presence of ultra fine quartz reduced the recovery of the magnetite. This indicates that the size of the gangue particles has a strong effect on the 
recovery of the valuable ones. Ran et al. (2019) also performed experiments using a multi-species mineral system. These flotation experiments investigated the effect of particle size on flotation performance for the separation of copper, gold and lead. This study showed that the most favourable size fraction for improving the recovery was an intermediate size of $-74+59 \mu \mathrm{m}$.

As well as understanding the effect of particle size on recovery, it is also important to understand the effect that different particle sizes have on froth stability. There have been several different bodies of work on this topic(Johansson and Pugh, 1992; Ip et al., 1999; Aktas et al., 2008; McFadzean et al., 2016; Norori-Mccormac et al., 2017; Mackay et al., 2018), yet the results are not conclusive. The majority of the work measures the dynamic froth stability in non-overflowing laboratory scale columns. Johansson and Pugh (1992) showed that whether or not fine particles will destabilise the froth depends on the hydrophobicity of the particles. They varied the contact angles of the particles in the feed and measured the resulting dynamic froth stability. The results showed that at low contact angles $\left(<40^{\circ}\right)$, fine particles $(26-44 \mu \mathrm{m})$ had little effect on the stability, intermediate angles $\left(\sim 65^{\circ}\right)$ gave the best stability whilst higher angles $\left(>80^{\circ}\right)$ destabilised the froth. Ip et al. (1999) measured the dynamic froth stability in a column with different particle sizes (from 45$130 \mu \mathrm{m}$ ) of a synthetic feed, consisting only of silica. They showed that, in general, smaller mean particle sizes led to higher froth stabilities. However, this was not a perfectly linear relationship; instead, there was a plateau at the intermediate particle sizes. Aktas et al. (2008) varied the particle size ( $d_{50}$ between $28 \mu \mathrm{m}$ and $75 \mu \mathrm{m}$ ) of a platinum group metal (PGM) ore in a froth stability column and showed a linear relationship where smaller feed sizes resulted in higher froth stabilities. A similar, inversely proportional relationship was presented by McFadzean et al. (2016), also using a synthetic ore $\left(d_{50}\right.$ between $15 \mu \mathrm{m}$ and $212 \mu \mathrm{m})$ in addition to several PGM ores ( $d_{50}$ between $30 \mu \mathrm{m}$ and $70 \mu \mathrm{m}$ ); the relationship obtained, however, was a power law rather than simply linear.

Unlike most of these studies, Norori-Mccormac et al. (2017) investigated the effects of particle size in a laboratory scale, continuously overflowing, mechanical flotation cell and used air recovery as the measure of froth stability (Moys, 1984). These results showed that the relationship between particle size and froth stability is not a simple one, but there is also a dependence on the superficial gas velocity in the system. At high superficial gas velocities the relationship is the same as those seen in Aktas et al. (2008) and McFadzean et al. (2016) in that smaller feed sizes result in an improved froth stability. However, at lower superficial gas velocities there is an intermediate feed size that results in the optimal stability. Most recently, Mackay et al. (2018) investigated the effects of varying the particle size on dynamic froth stability in a laboratory scale column for a copper tailings ore. These results showed that there were two stability regimes: the first was at finer particle sizes, where the relationship is the same as seen in other work, while at coarser particle sizes ( $d_{90}$ greater than $170 \mu \mathrm{m})$ there was an optimal particle size for improved froth stability at $d_{90}$ of $220 \mu \mathrm{m}$. This was found to be the case for a range of superficial gas velocities that are similar to industrial values. It is important to point out that the majority of these studies are conducted using synthetic ores or in nonoverflowing columns which are not necessarily representative of industrial flotation.

\subsection{Bench scale flotation cells}

Due to the complexities involved with carrying out experiments in an industrial setting, a vast amount of flotation research is done at the laboratory scale. The majority of laboratory scale testing, for mechanically stirred flotation, uses batch tests, e.g. tests conducted in a Denver cell (Wills and Finch, 2015). Batch tests are relatively simple to conduct and are often used due to their suitability for optimising flotation chemistry. However, these cells are limited in their usefulness to study other aspects of flotation performance since they cannot be operated at steady state. A continuous, bench-scale, flotation cell was developed by Norori-Mccormac et al. (2017) and was shown to operate in a manner similar to industrial flotation cells. In this cell, the overflowing concentrate is pumped back into the pulp phase allowing steady state to be achieved and maintained for over 
an hour. This is extremely beneficial to laboratory research as it provides a better comparison to industrial flotation froth behaviour than batch testing.

In order to relate experiments to industrial processes it is important to be able to quantify the flotation performance. There are various different metrics commonly used to do this, with concentrate grade and recovery being the most ubiquitous. Another valuable performance indicator is froth stability (Neethling and Brito-Parada, 2018). There are several different measures of stability depending on the type of system being investigated. When considering a continuous system, air recovery, or the fraction of air entering the cell that over flows the lip, has been shown to be a robust measure. It is defined in equation 1 :

$$
\alpha=\frac{Q_{\text {out }}}{Q_{\text {in }}}=\frac{v_{f} h w}{Q_{\text {in }}},
$$

where $\alpha$ is the air recovery, $Q_{\text {out }}$ is the air overflowing the cell in bubbles and not lost due to bursting, $Q_{i n}$ is the flow rate of air into the cell, $v_{f}$ is the overflowing froth velocity, $h$ is the height of the overflowing froth over the cell lip, and $w$ is the length of the lip of the cell. Equation 1 considers that flotation froths are very dry, particularly at the top of the froth where liquid fractions are very low. It is important to note that the relationship between air recovery and air rate is non linear. Hadler and Cilliers (2009) established that, when increasing the air rate, a peak in air recovery (PAR) can be seen, which is due to a tradeoff between froth stability and mobility. Hadler et al. (2010) demonstrated that, at industrial scale, changing the air flowrate into a flotation cell to the PAR resulted in an increased mineral recovery with only a small drop in the grade of the concentrate.

This work uses the continuously overflowing flotation cell first used by Norori-Mccormac et al. (2017) to investigate particle size effects on froth stability, using a copper tailings ore and thus allowing a closer comparison of the cell to industrial systems. It also makes it possible to understand better the relationships between different operating parameters, in particular the particle size of the feed and the superficial gas velocity, and froth stability for a copper tailings ore. In addition, this work expands on that done by Mackay et al. (2018) by using the same ore, from the same batch, but in a continuously overflowing system measuring air recovery as opposed to a non-overflowing column measuring dynamic froth stability. This allows a direct comparison between two different measures of stability. The results from Mackay et al. (2018) indicated that there were two stability regimes, one that follows the trends seen by other authors and a second that shows and optimum feed particle size for an improvement in froth stability and flotation performance. This paper focuses on this second region, with $d_{90}>150 \mu \mathrm{m}$, in order to investigate this trend further. This will have strong implications for furthering our understanding of the relationship between particle size, froth stability and flotation performance in order to improve the efficiency of tailings reprocessing by froth flotation.

\section{Materials and Methods}

\subsection{Materials}

The samples used in this study were obtained from a Chilean processing plant that reprocesses both historic and fresh copper tailings with copper grades of $0.27 \%$ and $0.12 \%$, respectively. Due to the nature of tailings, approximately $50 \%$ of the material entering the plant is less than $10 \mu \mathrm{m}$. The plant uses a primary hydrocyclone to split the material for processing. The hydrocyclone overflow stream has a $d_{90}$ of $63.7 \mu \mathrm{m}$ and the underflow stream has a $d_{90}$ of $279 \mu \mathrm{m}$. The underflow stream is then processed via flotation. Samples were obtained from the underflow and overflow streams of the primary hydrocyclone, as slurry, and then dried, resulting in two samples with different particle size distributions. This allowed the two samples to be combined in different ratios to produce the three different particle size distributions investigated in this work (table 1 and figure 1 ). The samples used for these experiments were obtained from the same batch that was used in Mackay et al. (2018) and the particle sizes were chosen in order to further investigate the local maximum in froth stability presented by Mackay et al. (2018). These particle size distributions were determined using a Malvern Mastersizer 3000e particle analyser. The Mastersizer 
uses laser diffraction and applies the Mie theory of light scattering. The copper content of the different was determined by atomic absorption as described in section 2.3 and is presented in table 1 .

Table 1: Particle size distributions and copper content for the three different feeds used.

\begin{tabular}{|c|ccc|c|}
\hline Feed & $\begin{array}{c}d_{10}, \\
{[\mu \mathrm{m}]}\end{array}$ & $\begin{array}{c}d_{50}, \\
{[\mu \mathrm{m}}\end{array}$ & $\begin{array}{c}d_{90}, \\
{[\mu \mathrm{m}]}\end{array}$ & $\begin{array}{c}\mathrm{Cu}, \\
{[\%]}\end{array}$ \\
\hline$A$ & 2.6 & 23.0 & 179.3 & 0.27 \\
$B$ & 2.9 & 30.2 & 219.1 & 0.27 \\
$C$ & 3.3 & 47.1 & 253.4 & 0.32 \\
\hline
\end{tabular}

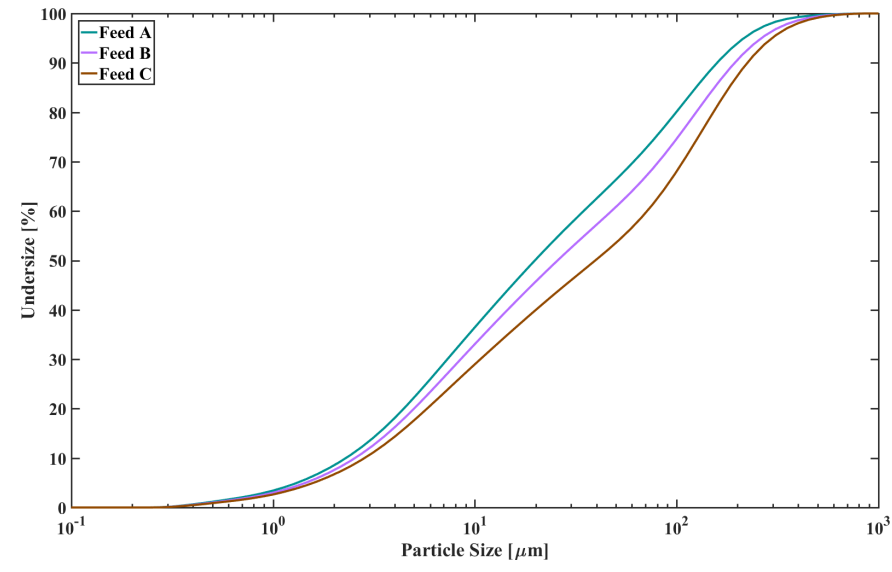

Figure 1: Cumulative size distributions of the four different feeds used.

The mineralogy of the feeds used in this study was analysed by QEMSCAN (quantitative evaluation of minerals by scanning electron microscopy). A QEMSCAN E430 in bulk mineralogical analysis measurement mode was used with a measurement time of 2.5 hrs and an acceleration voltage of $20 \mathrm{kV}$. The software used were iMeasure v.4.3 for data acquisition and iDiscover v.4.3 for data processing. The QEMSCAN was calibrated using Quartz, Copper and Gold standards, with preset values of 44, 130 and 232 respectively.

The reagent environment used for these experiments was developed by Molina et al. (2016) and is the same as was used in Mackay et al. (2018). The collector used was Sodium Isopropyl Xanthate at $50 \mathrm{~g} \mathrm{t}^{-1}$ and the frother was DowFroth 400 (supplied by Nasaco Ltd.) at $20 \mathrm{~g} \mathrm{t}^{-1}$. Lime, $\mathrm{CaO}$ (supplied by Arcos Organics), was used to ensure a constant $\mathrm{pH}$ of 9 across all experiments.

\subsection{Continuously overflowing flotation cell}

The experimental system used in this work is a four litre continuously overflowing flotation cell (shown in figure 2) developed by and described in NororiMccormac et al. (2017). The overflowing concentrate is pumped back into the cell allowing for continuous operation and for steady state conditions to be achieved.

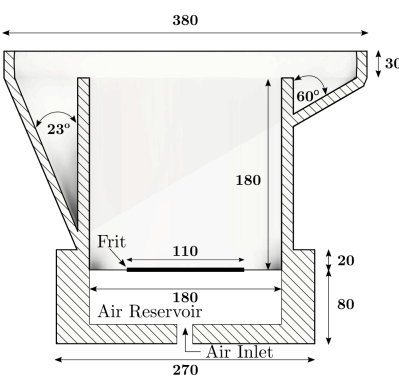

(a) Schematic of the flotation cell

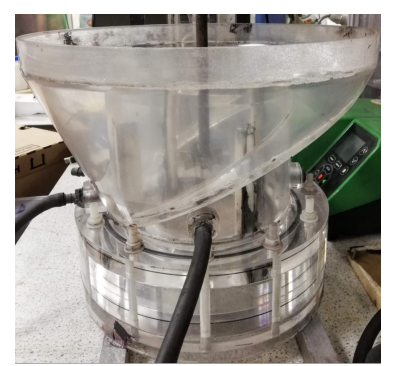

(b) Photograph of the flotation cell
Figure 2: Details of the design of the continuously overflowing flotation cell. The concentrate is pumped from the launder back into the pulp zone of the cell. Measurements given in the schematic in (a) are in millimetres.

For each experiment, $900 \mathrm{~g}$ of copper tailings ore, with one of the three different size distributions in table 1 , were combined with $2.9 \mathrm{~L}$ of deionised water to form the slurry. The slurry was then added to the cell along with the frother and collector and was then agitated, at $950 \mathrm{rpm}$, to condition for 15 minutes. This was the same process as was used by Norori-Mccormac et al. (2017). Four different superficial gas velocities $\left(J_{g}\right)$ were used across the experiments, $0.92 \mathrm{~cm} \mathrm{~s}^{-1}, 1.05 \mathrm{~cm} \mathrm{~s}^{-1}, 1.18 \mathrm{~cm} \mathrm{~s}^{-1}$ and $1.31 \mathrm{~cm} \mathrm{~s}^{-1}$. These values of $J_{g}$ are similar to those used industrially (Mesa and Brito-Parada, 2019) as well as those used in Mackay et al. (2018).

For each experiment, 6 different conditions were run; conditions included each of the four superficial gas velocities, with two of them repeated. The order in which the conditions were performed was randomised. Each condition was run for 15 minutes, which was made up of 5 minutes without measurement to enable steady state to be achieved, and 10 minutes of measurement time. An on-line laser (ifm electronics, 01D300) was used to measure the over- 
flowing froth height via LabVIEW. A web camera (Logitech, C525) was combined with FrothTracker, an in-house, block matching, image analysis program, and used to measure the overflowing froth velocity. The measured values of overflowing froth height and velocity allowed air recovery to be calculated using equation 1.

\subsection{Sample Analysis}

Froth samples for each condition were collected using a 3D printed scoop that was inserted into the launder of the cell for 10 seconds. They were then weighed and dried in order to calculate the solids content of the concentrate and the solids flowrate to the concentrate. The samples were then analysed for copper content (Wheal Jane Laboratories, Cornwall, $U K)$. The samples were first prepared by hydrochloric acid attack and then the copper content analysed using a Thermo Fisher Scientific iCE 3300 Atomic Absorption Spectrometer.

Due to the fact that the concentrate is recycled back into the pulp of the cell, effectively acting as the feed stream, there is no tailings stream in this cell. Copper recovery was therefore not calculated in the traditional way, instead the copper grade of the concentrate and the solids flowrate over the lip of the cell were used to calculate the copper recovery per minute. This can be done using equation 2 ,

$$
\text { Recovery }=\frac{G_{c} F_{c}}{G_{f} M_{f}}
$$

where $G, F$ and $M$ represent the grade, flowrate and mass, while the subscripts $c$ and $f$ correspond to the concentrate and feed streams. The mass of the feed is used as the mass of solids used in the experiments $(900 \mathrm{~g})$ and the flowrate to the concentrate is measured in grams per minute.

\section{Results \& Discussion}

\subsection{Sample Characterisation}

The detailed mineralogy of each of the different feeds can be seen in figure 3 . The mineralogy shows that, in general, there is no large difference in the mineralogy of the different feeds used. The liberation by size of the chalcopyrite, for particles greater than $75 \mu \mathrm{m}$ and less than $75 \mu \mathrm{m}$, is shown figure 4 . For all three feeds, the majority of the chalcopyrite has a liberation of lower than $50 \%$ and this poorly liberated chalcopyrite is mostly over $75 \mu \mathrm{m}$. Feeds $A$ and $B$ contain no chalcopyrite that is more than $50 \%$ liberated and over $75 \mu \mathrm{m}$, whereas feed $C$ contains a large proportion of chalcopyrite that fits into this category. The chalcopyrite in feeds $B$ and $C$ is better liberated than feed $A$, with a higher proportion of the chalcopyrite being over $50 \%$ liberated.

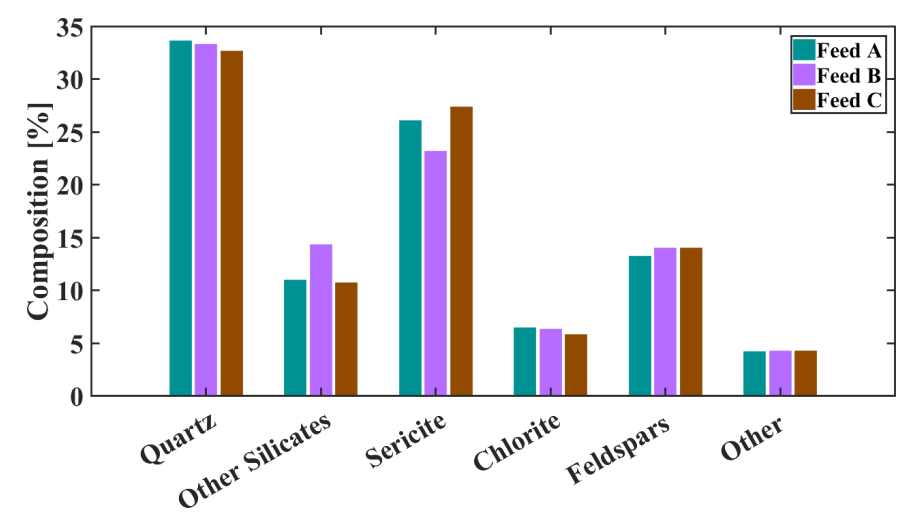

(a) Mineralogy for high value minerals

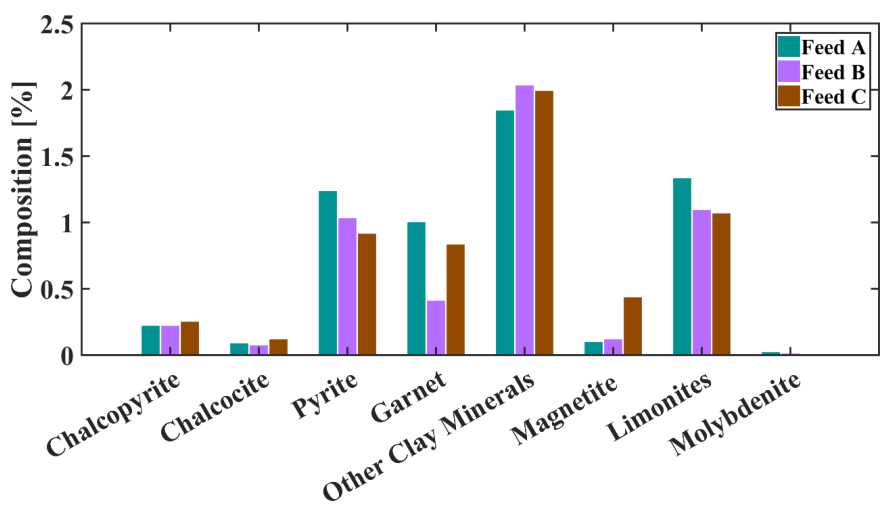

(b) Mineralogy for low value minerals

Figure 3: Mineral composition of the different feeds, from the QEMSCAN analysis, split into (a) minerals that comprise more than $5 \%$ of the feed and (b) minerals that are less than $2.5 \%$ of the feed.

\subsection{Froth Stability}

In order to verify that the changes in air recovery are caused by changes in operating conditions and 


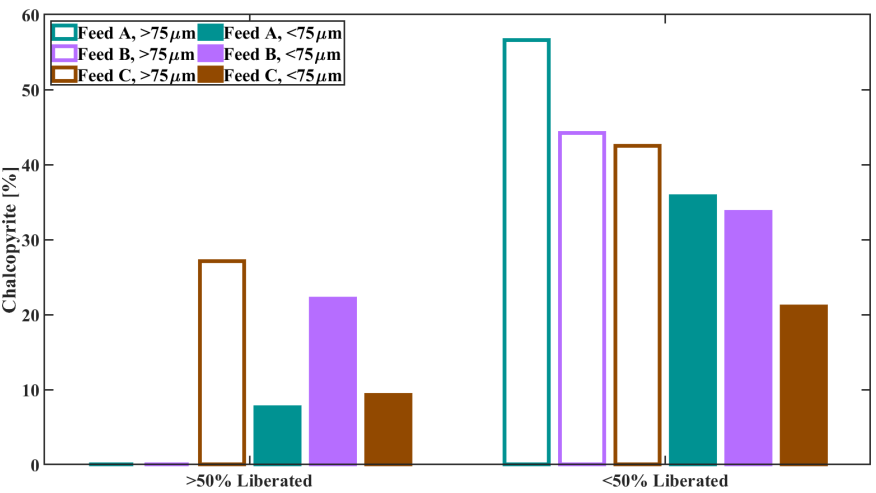

Figure 4: Chalcopyrite liberation by size from QEMSCAN analysis of the three different feeds.

not by changes in the system with time, tests were run for an hour and a half to ensure the operation remained at steady state. Figure 5 shows the moving average of the air recovery over 90 minutes for an experiment at a $J_{g}=0.92 \mathrm{~cm} \mathrm{~s}^{-1}$. The data was divided into six, 15 minute windows and the data in the last 10 minutes of each window were averaged (the data in the light grey vertical bands) to analyse the change in air recovery over time. The average value for each of these 10 minute windows is presented in figure 5, with black dots and error bars representing a 95\% confidence interval. The overall $95 \%$ confidence interval is presented in figure 5 with a horizontal dark grey band.

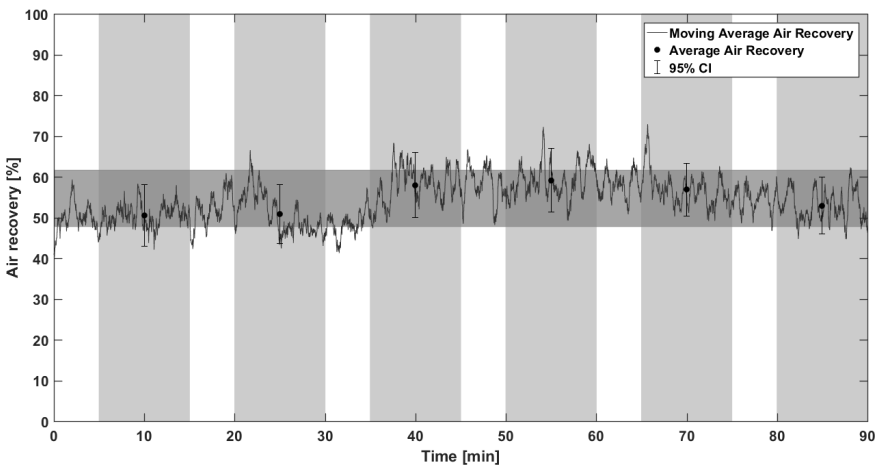

Figure 5: The variation in air recovery over time at a constant condition, with 10 minute measurement windows highlighted by light grey vertical bands and a confidence band for the average value of air recovery represented by the dark grey horizontal band. Error bars represent a $95 \%$ confidence interval.

A heat map of the air recovery data for varying feed size distributions and superficial gas velocities can be seen in figure 6 . When investigating the effects of varying superficial gas velocity for a constant feed size (the rows of the heat map) only feed $A$ displays a peak in air recovery which is at a superficial gas velocity of $1.18 \mathrm{~cm} \mathrm{~s}^{-1}$. At coarser feeds, there is no peak in air recovery. Figure 6 shows that varying the particle size distribution of the feed for a given superficial gas velocity (the columns of the heat map) has a stronger effect on the air recovery; feeds $B$ and $C$ result in higher air recoveries for all superficial gas velocities investigated.

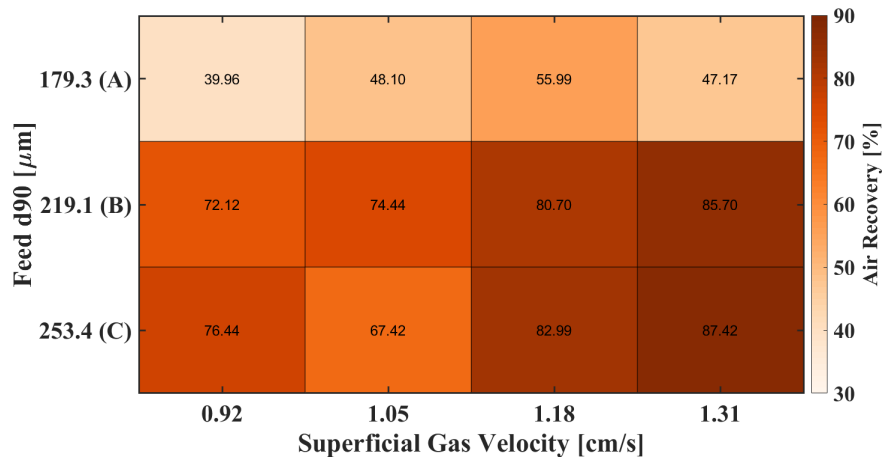

Figure 6: Heat map of air recovery for different feed $d_{90}$ s and superficial gas velocities.

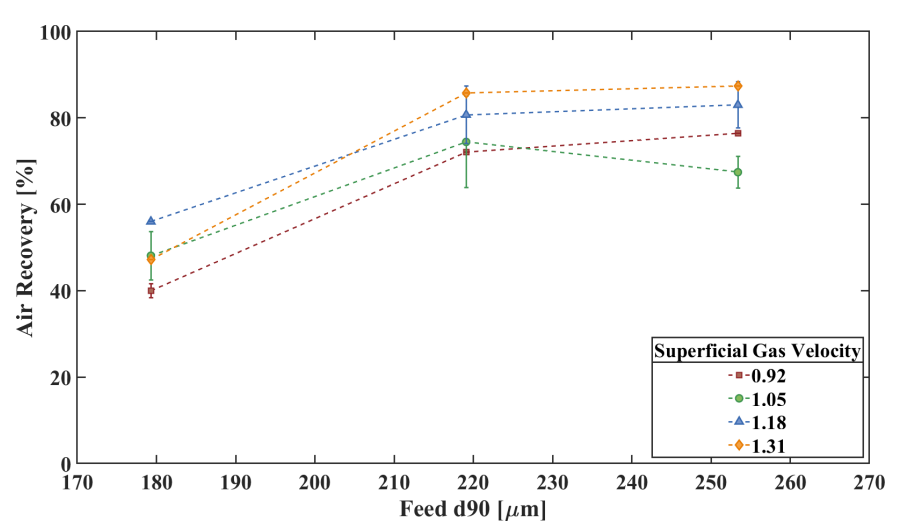

Figure 7: The variation in air recoveries with varying feed size at different superficial gas velocity. Error bars are one standard deviation.

For a better understanding of the relationship between feed size and air recovery, the data are presented in more detail in figure 7 . The air recovery with varying feed size is plotted for each superficial gas velocity with error bars as one standard deviation. An ANOVA test was performed on these data (table 2), which shows that only changing the feed size had a statistically significant effect on the air recovery. This indicates that, regardless of the superficial gas velocity used, there is a clear improvement in froth stability at coarser feed sizes, with $d_{90}$ be- 
Table 2: ANOVA table of air recovery with particle size distribution.

\begin{tabular}{cccccc}
\hline & Sum of & Degrees of & Mean of & & \\
Source & Squares & Freedom & Squares & $F$-Stat & $p$-Value \\
\hline Feed Size & 3329.7 & 2 & 1664.85 & 10.79 & 0.0103 \\
Superficial Gas Velocity & 436.05 & 3 & 145.35 & 0.94 & 0.4772 \\
Interaction & 222.77 & 6 & 37.13 & 0.24 & 0.9466 \\
Error & 926 & 6 & 154.33 & & \\
Total & 5495.59 & 17 & & & \\
\hline
\end{tabular}

tween $220 \mu \mathrm{m}$ and $260 \mu \mathrm{m}$. These data also correlate well with the relationships shown in the experiments performed by Norori-Mccormac et al. (2017) at the lower two superficial gas velocities they investigated, and the relationship shown by Mackay et al. (2018).

The experiments in this study were conducted using the same batch of ore as was used by Mackay et al. (2018), allowing a direct comparison between the two measures of froth stability, i.e. dynamic froth stability and air recovery, to be made. Figure 8 shows the two data sets plotted together, with dynamic froth stability on the left hand axis and air recovery on the right hand axis. Both data sets show high froth stabilities at approximately the same feed size, $d_{90}$ of $\sim 220 \mu \mathrm{m}$. The air recovery data, however, does not have a clear maximum value. It is likely that a maximum occurs at a feed particle size distribution between $B$ and $C$ corresponding directly with the peak in dynamic froth stability.

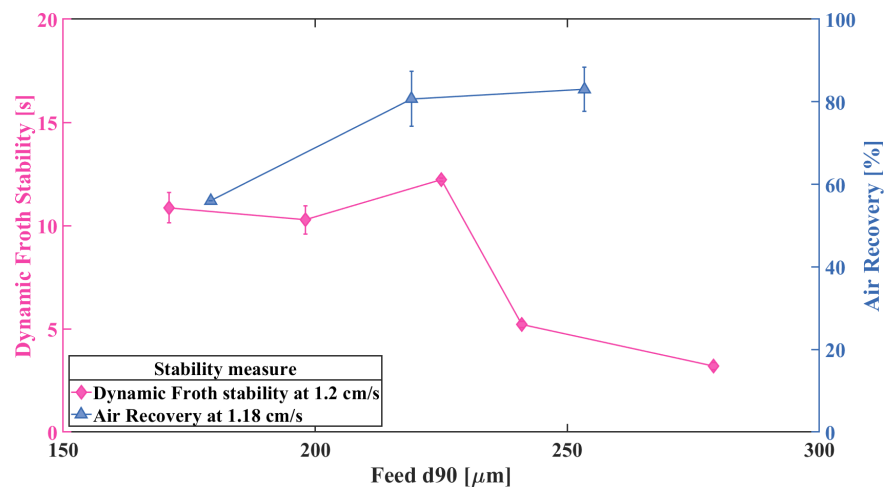

Figure 8: Comparison of dynamic froth stability (diamonds and left hand axis) and air recovery (triangles and right hand axis) for the same batch of copper tailings ore. Error bars are one standard deviation.

\subsection{Flotation performance}

Whilst the feeds $B$ and $C$ were shown to result in the highest froth stability, it is important to understand how this trend is reflected in the flotation performance. One of the benefits of running experiments in the continuously overflowing cell, is that the air recovery can be measured while, at the same time, samples of the overflowing froth can be taken to determine flotation performance. The copper content of the feed and concentrate samples was analysed to determine grade and recovery. This was only done for experiments with superficial gas velocities of $0.92 \mathrm{~cm} \mathrm{~s}^{-1}$ and $1.18 \mathrm{~cm} \mathrm{~s}^{-1}$.

Figure 9 shows the copper grade of the concentrate from experiments with a superficial gas velocity of $0.92 \mathrm{~cm} \mathrm{~s}^{-1}$ and $1.18 \mathrm{~cm} \mathrm{~s}^{-1}$. It is observed that the grade decreases as superficial gas velocity increases. The analysis of variance results in table 3 show that this change is significant. This behaviour is expected, as higher superficial gas velocities will result in higher entrainment factors and therefore a reduced grade (Neethling and Cilliers, 2009). The analysis also shows that there is no statistically significant difference in the concentrate grade with different feed sizes. 


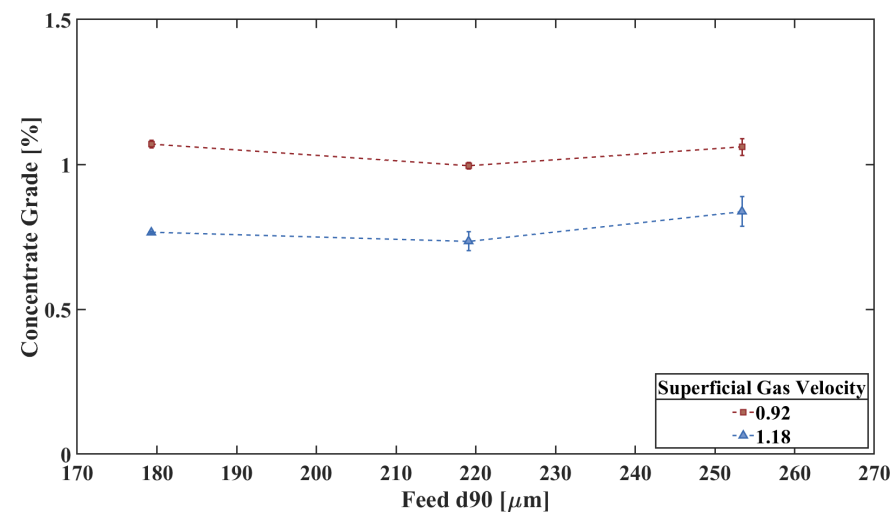

Figure 9: Concentrate grade for samples taken at $0.92 \mathrm{~cm} \mathrm{~s}^{-1}$ and $1.18 \mathrm{~cm} \mathrm{~s}^{-1}$. Error bars are 1 standard deviation.

Figure 10 shows that the copper recovery is higher for the higher superficial gas velocity, which is often associated with an increase in mass pull. Feed $B$, which showed an improvement in air recovery, also has the best copper recovery at both superficial gas velocities. The analysis of variance in table 4 shows that both the feed size and the superficial gas velocity had a significant effect on the copper recovery. This is in line with the experimental results presented in Mackay et al. (2018), which showed that the feed with a similar particle size distribution to $B$, and which yielded a local peak in dynamic froth stability, corresponded to an improvement in copper recovery. Feed $C$, with a similar air recovery value to feed $B$, shows a decrease in flotation performance, despite the fact that they also have similar mineralogical composition. This indicates that the particle size distribution of feed $B$ is optimal for an improvement in flotation performance.

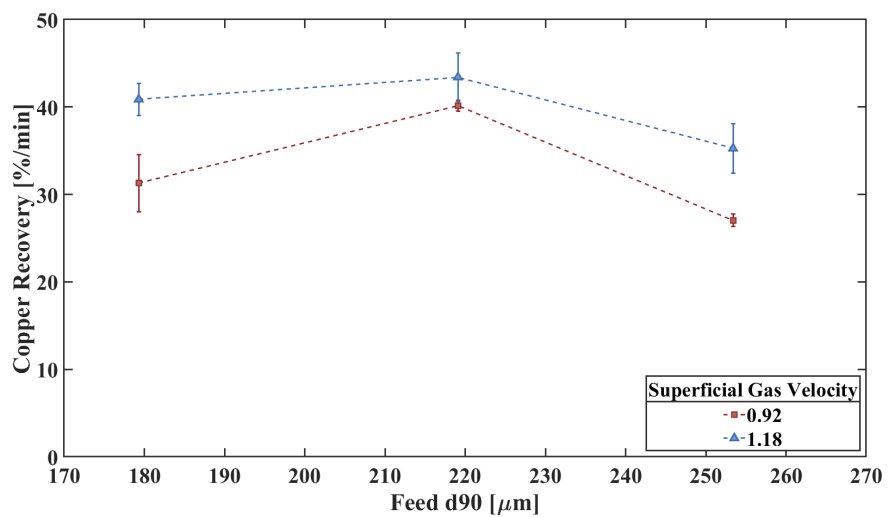

Figure 10: Copper recovery to the concentrate for samples taken at $0.92 \mathrm{~cm} \mathrm{~s}^{-1}$ and $1.18 \mathrm{~cm} \mathrm{~s}^{-1}$. Error bars are 1 standard deviation.

\subsection{Implications for reprocessing mine tailings via froth flotation}

The samples of copper tailings used in this study were obtained from a plant currently reprocessing historic and fresh tailings material from a mine in Chile. The plant uses a primary hydrocyclone to split the material before processing. The underflow from the hydrocyclone, with a $d_{90}$ of $279 \mu \mathrm{m}$, is then processed via froth flotation.

The findings from section 3.3 indicate that the size distribution of the material currently being sent to flotation in this plant is not optimal. Instead, altering the cutsize of the hydrocyclone to produce a feed particle size distribution with a $d_{90}$ of approximately $220 \mu \mathrm{m}$ would result in improved copper recovery from the tailings material. Altering the particle size distribution of the feed to the flotation circuit would also reduce the amount of material sent to final tailings, therefore reducing the environmental impacts from mine waste.

Previous work by other authors (Ip et al., 1999; Norori-Mccormac et al., 2017) has shown that the relationship between particle size and froth stability is not a simple one. The work in this paper compounds that fact, clearly showing that there can be an optimal particle size distribution for froth stability that correlates to an improvement in flotation performance. Evidence suggests that this behaviour is 
Table 3: ANOVA table of concentrate grade with particle size distribution and superficial gas velocity.

\begin{tabular}{cccccc}
\hline & Sum of & Degrees of & Mean of & & \\
Source & Squares & Freedom & Squares & $F$-Stat & $p$-Value \\
\hline Feed Size & 0.01911 & 2 & 0.00955 & 2.29 & 0.1438 \\
Superficial Gas Velocity & 0.27563 & 1 & 0.27563 & 66.05 & 0 \\
Interaction & 0.00455 & 2 & 0.00227 & 0.55 & 0.5934 \\
Error & 0.05007 & 12 & 0.00417 & & \\
Total & 0.39589 & 17 & & & \\
\hline
\end{tabular}

Table 4: ANOVA table of copper recovery with particle size distribution and superficial gas velocity.

\begin{tabular}{cccccc}
\hline & $\begin{array}{c}\text { Sum of } \\
\text { Squares }\end{array}$ & $\begin{array}{c}\text { Degrees of } \\
\text { Freedom }\end{array}$ & $\begin{array}{c}\text { Mean of } \\
\text { Squares }\end{array}$ & $F$-Stat & $p$-Value \\
\hline Feed Size & 301.12 & 2 & 150.56 & 5.43 & 0.021 \\
Superficial Gas Velocity & 197.59 & 1 & 197.59 & 7.12 & 0.0205 \\
Interaction & 29.456 & 2 & 14.728 & 0.53 & 0.6013 \\
Error & 332.904 & 12 & 27.742 & & \\
Total & 881.861 & 17 & & & \\
\hline
\end{tabular}

exhibited by a variety of particle systems. It would therefore be wise for a tailings reprocessing plant to conduct simple froth stability tests to determine the optimal particle size distribution to improve recovery.

\section{Conclusions}

This study has investigated the effects of particle size, at a range of superficial gas velocities, on the froth stability and flotation performance of a copper tailings ore. These experiments were performed using a continuously overflowing bench scale flotation cell which is more representative of industrial systems than cells used for traditional batch tests. This cell had previously only been used to investigate effects with a single species, idealised system. In this study the cell was used to investigate a complex copper tailings ore, and was shown to be able to operate at steady state for an extended period of time.

The experiments in this study have enabled us to further investigate the operating conditions that yielded a local peak in dynamic froth stability previously shown in Mackay et al. (2018). For the first time, there has been a direct comparison between two different measures of froth stability: dynamic froth stability and air recovery. The results have shown that, for the same tailings ore, the feed particle size distribution that resulted in a local maximum in dynamic froth stability also yielded a maximum in air recovery. This helps to compound the fact that it is not simply a fine particle size distribution that improves froth stability, but that an intermediate distribution can result in the optimal froth stability. This effect was observed at multiple superficial gas velocities.

Flotation performance was also investigated. We show that the particle size distribution which yielded the optimal froth stability, both in terms of air recovery and dynamic froth stability, resulted in the highest copper recoveries. In the case of the processing plant from where the samples in this study were obtained, altering the particle size distribution of the material sent to flotation, to the optimal shown in this work, would not only translate into improved flotation performance but would also reduce the amount of material sent to final tailings.

The findings in this work have strong implications for the reprocessing of mineral resources from tailings, suggesting that froth stability tests to find the optimal particle size distribution should be carried out before reprocessing tailings by froth flotation. 
This will allow for enhanced mineral recoveries to be achieved, thus contributing to a more efficient use of resources and the reduction of environmental impacts associated to mineral tailings. Future work will be carried out using the continuously overflowing bench scale cell to investigate a greater number of particle size distributions and a wider range of tailings material. This would further improve our understanding of how the relationship between particle size distribution and froth stability change with variations in mineralogy.

\section{Acknowledgements}

I. Mackay's PhD was supported by the Engineering and Physical Sciences Research Council (award number 1661853) and the Society for Chemical Industry.

\section{References}

Adiansyah, J. S., Rosano, M., Vink, S., Keir, G., 2015. A framework for a sustainable approach to mine tailings management: disposal strategies. Journal of Cleaner Production 108, 1050-1062.

Aktas, Z., Cilliers, J., Banford, A., 2008. Dynamic froth stability: Particle size, airflow rate and conditioning time effects. International Journal of Mineral Processing 87 (1-2), 65-71.

Alcalde, J., Kelm, U., Vergara, D., 2018. Historical assessment of metal recovery potential from old mine tailings: A study case for porphyry copper tailings, Chile. Minerals Engineering 127, 334-338.

Babel, B., Penz, M., Schach, E., Boehme, S., Rudolph, M., 2018. Reprocessing of a Southern Chilean Zn Tailing by FlotationA Case Study. Minerals 8 (7), 295.

Chen, T., Lei, C., Yan, B., Xiao, X., 2014. Metal recovery from the copper sulfide tailing with leaching and fractional precipitation technology. Hydrometallurgy 147-148, 178-182.
Edraki, M., Baumgartl, T., Manlapig, E., Bradshaw, D., Franks, D. M., Moran, C. J., 2014. Designing mine tailings for better environmental, social and economic outcomes: a review of alternative approaches. Journal of cleaner production 84, 411420.

Falagán, C., Grail, B. M., Johnson, D. B., 2017. New approaches for extracting and recovering metals from mine tailings. Minerals Engineering 106, 7178.

Feng, D., Aldrich, C., 1999. Effect of particle size on flotation performance of complex sulphide ores. Minerals Engineering 12 (7), 721-731.

Fuerstenau, M. C., Jameson, G. J., Yoon, R.-H., 2007. Froth flotation: a century of innovation. SME.

Gordon, R. B., 2002. Production residues in copper technological cycles. Resources, Conservation and Recycling 36 (2), 87-106.

Hadler, K., Cilliers, J., 2009. The relationship between the peak in air recovery and flotation bank performance. Minerals Engineering 22, 451-455.

Hadler, K., Smith, C., Cilliers, J., 2010. Recovery vs. mass pull: The link to air recovery. Minerals Engineering 23 (11), 994-1002.

Ip, S., Wang, Y., Toguri, J., 1999. Aluminum foam stabilization by solid particles. Canadian Metallurgical Quarterly 38 (1), 81-92.

Johansson, G., Pugh, R., 1992. The influence of particle size and hydrophobicity on the stability of mineralized froths. International Journal of Mineral Processing 34 (1-2), 1-21.

Leistner, T., Embrechts, M., Leißner, T., Chelgani, S. C., Osbahr, I., Möckel, R., Peuker, U. A., Rudolph, M., 2016. A study of the reprocessing of fine and ultrafine cassiterite from gravity tailing residues by using various flotation techniques. Minerals Engineering 96-97, 94-98.

Leistner, T., Peuker, U. A., Rudolph, M., 2017. How gangue particle size can affect the recovery of ultrafine and fine particles during froth flotation. Minerals Engineering 109, 1-9. 
Lutandula, M. S., Maloba, B., 2013. Recovery of cobalt and copper through reprocessing of tailings from flotation of oxidised ores. Journal of Environmental Chemical Engineering 1 (4), 1085-1090.

Mackay, I., Mendez, E., Molina, I., Videla, A., Cilliers, J., Brito-Parada, P., 2018. Dynamic froth stability of copper flotation tailings. Minerals Engineering 124, 103-107.

McFadzean, B., Achaye, I., Wiese, J., Chidzanira, T., Harris, M., 2016. The effect of particle size on froth stabilities of different ores. XXVII International Mineral Processing Congress, 1-11.

Mesa, D., Brito-Parada, P. R., 2019. Scale-up in froth flotation: A state-of-the-art review. Separation and Purification Technology 210, 950-962.

Miettinen, T., Ralston, J., Fornasiero, D., 2010. The limits of fine particle flotation. Minerals Engineering 23 (5), 420-437.

Molina, I., Martins, P., Videla, A., 2016. On the interaction effect between xanthate colletor, frothers and solids: Alaboratory characterization of copper sulfide flotation. Procemin2016, 12th International Mineral Processing Conference, Santiago, Chile.

Moys, M., 1984. Residence time distributions and mass transport in the froth phase of the flotation process. International Journal of Mineral Processing 13 (2), 117-142.

Neethling, S., Brito-Parada, P., 2018. Predicting flotation behaviour-the interaction between froth stability and performance. Minerals Engineering 120, 60-65.

Neethling, S., Cilliers, J., 2009. The entrainment factor in froth flotation: Model for particle size and other operating parameter effects. International Journal of Mineral Processing 93 (2), 141-148.

Norori-Mccormac, A., Brito-Parada, P. R., Hadler, K., Cole, K., Cilliers, J. J., 2017. The effect of particle size distribution on froth stability in flotation. Separation and Purification Technology 184, 240 247.
Rahman, R. M., Ata, S., Jameson, G. J., 2012. The effect of flotation variables on the recovery of different particle size fractions in the froth and the pulp. International Journal of Mineral Processing 106-109, 70-77.

Ran, J.-c., Qiu, X.-y., Hu, Z., Liu, Q.-j., Song, B.-X., Yao, Y.-q., 2019. Effects of particle size on flotation performance in the separation of copper, gold and lead. Powder Technology 344, 654-664.

Valderrama, L., Rubio, J., 2007. Unconventional column flotation of low-grade gold fine particles from tailings. International Journal of Mineral Processing $86,75-84$.

Vieira, A. M., Peres, A. E., 2007. The effect of amine type, $\mathrm{pH}$, and size range in the flotation of quartz. Minerals Engineering 20 (10), 1008-1013.

Wills, B. A., Finch, J., 2015. Wills' mineral processing technology: an introduction to the practical aspects of ore treatment and mineral recovery. Butterworth-Heinemann.

Yang, X., Huang, X., Qiu, T., 2015. Recovery of zinc from cyanide tailings by flotation. Minerals Engineering $84,100-105$.

Yin, Z., Sun, W., Hu, Y., Zhang, C., Guan, Q., Wu, K., 2018. Evaluation of the possibility of copper recovery from tailings by flotation through benchscale, commissioning, and industrial tests. Journal of cleaner production 171, 1039-1048. 